\title{
Structure and Optical Properties of the $\mathrm{CdS} / \mathrm{Cd}_{2 \mathrm{x}}(\mathrm{CuIn})_{1}$ - ${ }_{x} \mathbf{S}_{2}$ Heterojunction Prepared by Chemical Spray Pyrolysis
}

\author{
Mohammed Z. AL-Rawiand Hamid S. AL-Jumaili \\ Department of Physics, College of Education for Pure Sciences, University of Anbar, Iraq
}

\begin{abstract}
The structural and optical properties of the $\mathrm{CdS}, \mathrm{Cd}_{2 \mathrm{x}}(\mathrm{CuIn})_{1-\mathrm{x}} \mathrm{S}_{2}$ (CCIS) thin films, at $\mathrm{x}=0.2$,heterojunction were studied in the present paper. The heterojunction films deposited successfully on glass slides using by the spray pyrolysis technique at $623 \mathrm{~K}$. The thin films CdS, CCIS and the heterojunction ITO/CdS/CCIS were characterized by using x-ray diffraction. This is to find the polycrystalline series of the CdS, and CCIS solid solution with many phases as a mixture of chalcopyrite and zinc blend. The CdS, and CCIS thin films have a grain size $35 \mathrm{~nm}$, and $16 \mathrm{~nm}$ respectively. The surface morphology was characterized by using atomic force microscopy (AFM) technique. The optical properties of the prepared thin films were investigated by using a UV-VIS spectrophotometer in the wavelength of $300 \mathrm{~nm}$ to $1100 \mathrm{~nm}$. The films, ITO, $\mathrm{CdS}$, and CCIS show direct transition with optical energy gap (Eg) values 3.52, 2.42, and $1.7 \mathrm{eV}$ respectively. The optical transmission (T),absorption (A) andrefractive index (n) were also discussed
\end{abstract}

Keywords: The ITO/CdS/Cd ${ }_{2 x}(\mathrm{CuIn})_{1-x} \mathrm{~S}_{2}$ Structure, Optical, heterojunction and thin films..

\section{INTRODUCTION}

The chalcopyrite compound copper indium disulfide, $\mathrm{CuInS}_{2}$, is one of the most promising candidates to substitute $\mathrm{CuInSe}$ as absorber material for photovoltaic applications[1]. Solar cell compounds such as $\mathrm{Cu}\left(\mathrm{In}_{1-}\right.$ ${ }_{x} \mathrm{Ga}_{\mathrm{x}}$ )Se2, CuInSe2(CISe), and CuInS2 (CIS) have received much attention from research groups around the world because of their potential properties, such as high efficiency, reliability, and stability[2] . Most of the reported studies are on the development of heterojunction between p-type CuInS2 and n-CdS[3-5].Thin CdS films are deposited as intermediate layers to improve the interface properties and a chemical buffer layer to protect the CuInS2 or CdTe during the subsequent processing .[6] Therefore, phase relations involving CuInS2 and CdS have to be investigated to assess possible element inter-diffusion at the p-n hetrojunction and to provide additional information on solid solution and possible intermediate phases [7].Thus, by taking the similarity of their crystalline structures into account, $\mathrm{CdS}$ doped with $\mathrm{CuInS} 2$ to form $(\mathrm{CuIn})_{\mathrm{x}} \mathrm{Cd}_{2(1-\mathrm{x})} \mathrm{S}_{2}$ complexs which could be identified for improving the photocatalytic activity and stability of CdS [8]. Many techniques including electrodeposition [9], spray pyrolysis [2], vacuum evaporation [10], and chemical bath deposition CBD [11], have been used to produce the device layers [6]. Theaim of the projectisto prepare $\mathrm{ITO} / \mathrm{CdS} / \mathrm{Cd}_{2 \mathrm{x}}(\mathrm{CuIn})_{1-\mathrm{x}} \mathrm{S}_{2}$ heterojunction through spray pyrolysis and to study its structure, and optical properties.

\section{EXPERMENTAL}

TheITO/CdS/ $\mathrm{Cd}_{2 x}(\mathrm{CuIn})_{1-\mathrm{x}} \mathrm{S}_{2}$ heterojunction, with $\mathrm{x}=0.2$, was prepared via chemical spray pyrolysis. The indium tin oxide (ITO), $\mathrm{CdS}$, and $\mathrm{Cd}_{2 \times}(\mathrm{CuIn})_{1-\mathrm{x}} \mathrm{S}_{2}$ thin films were prepared by mixing $0.1 \mathrm{M}$ and spraying an aqueous solution of $\left(\mathrm{InCl}_{3}, \mathrm{Sncl}_{2}\right)$ to obtained ITO, deposited on micro glass slides which were first cleaned with detergent water and then dipped in acetone.The cadmium sulfide $\mathrm{CdS}\left(\mathrm{CdCl}_{2}\right.$, thiourea $\left.\left[\mathrm{CS}\left(\mathrm{NH}_{2}\right)_{2}\right]\right)$, at ratio 1:1 deposited on ITO, and $\mathrm{Cd}_{2 \mathrm{X}}(\mathrm{CuIn})_{1-\mathrm{x}} \mathrm{S}_{2}\left(\mathrm{CdCl}_{2}, \mathrm{CuCl}_{2}, \mathrm{InCl}_{3}\right.$, thiourea $\left.\left[\mathrm{CS}\left(\mathrm{NH}_{2}\right)_{2}\right]\right)$ at ratio 0.4:0.8:0.8:2, deposited on CdS. The distance between the nozzle and the substrate at $45 \mathrm{~cm}$. The automated spray solution is transferred to the het substrate could be kept at the normalized deposition temperature of $623 \mathrm{~K}$ by using filtered air as carrier gas at a flow rate normalized to approximately $3 \mathrm{ml} / \mathrm{min}$. To prevent the substrate from excessively cooling, we sprayed the prepared solution on the substrate for 10 s with $15 \mathrm{~s}$ intervals. Using the optical method, we measured the thicknesses of the films of heterojunction, ITO at $300 \mathrm{~nm}, \mathrm{CdS}$ at $350 \mathrm{~nm}$, and CCIS at 910 $\mathrm{nm}$. The nature of the growth and structure characteristics of the prepared thin films and heterojunction were determined via X-ray diffraction(XRD) by using a Philips PW1840 diffractometer with $\mathrm{Cu}-\mathrm{Ka}$ target. The morphology of the films was determined via atomic force microscopy (AFM) (AA 3000; Angstrom Advanced Inc.). The UV-VIS spectrophotometer (Tenway 6800 UV-VIS) was used to measure the absorptance and transmittance in the wavelength range of $300 \mathrm{~nm}$ to $1100 \mathrm{~nm}$, and from these measurements, the optical parameters were calculated. 


\section{RESULTS AND DISCUSSION}

In order to study the characterization of each layer of the heterojunction solar cell, these layers were deposited on glass slides, so the structural and optical were studied and correlated with preparation parameters to optimize the best conditions fitting the solar cell performance.

\section{A. XRD analysis and surface morphology}

The structure of the prepared thin films and the heterojunction were examined via XRD. Fig. 1 shows that the polycrystalline film $\mathrm{Cd}_{2 \mathrm{x}}(\mathrm{CuIn})_{1-\mathrm{x}} \mathrm{S}_{2}$ at $\mathrm{x}=0.2$ has $\mathrm{CuInS}_{2}, \mathrm{CdS}, \mathrm{In}_{2} \mathrm{~S}_{3}$, and CCIS peak, indicating that the $\mathrm{Cd}_{2 \mathrm{x}}(\mathrm{CuIn})_{1-\mathrm{x}} \mathrm{S}_{2}$ system forms a solid solution. This is similar to the observed by Ren et al.[8],Marushko et al.[12], and Hamid et al.[13]. The analysis of the XRD patterns shows that the $\mathrm{CuInS}_{2}$ structure is a tetragonal chalcopyrite phase and a hexagonal or cubic phase for CdS as shown in Fig. 1, this is similar to the observed by A.AYadav et al.[14]. The average grain size of the CCIS, and CdSis calculated from the full width at half maximum (FWHM) of the (101) line of the film, byusing the scherrer formula [15] were 16, and $35 \mathrm{~nm}$, respectively.These results agree with those of Ravichandran et al.[16], and

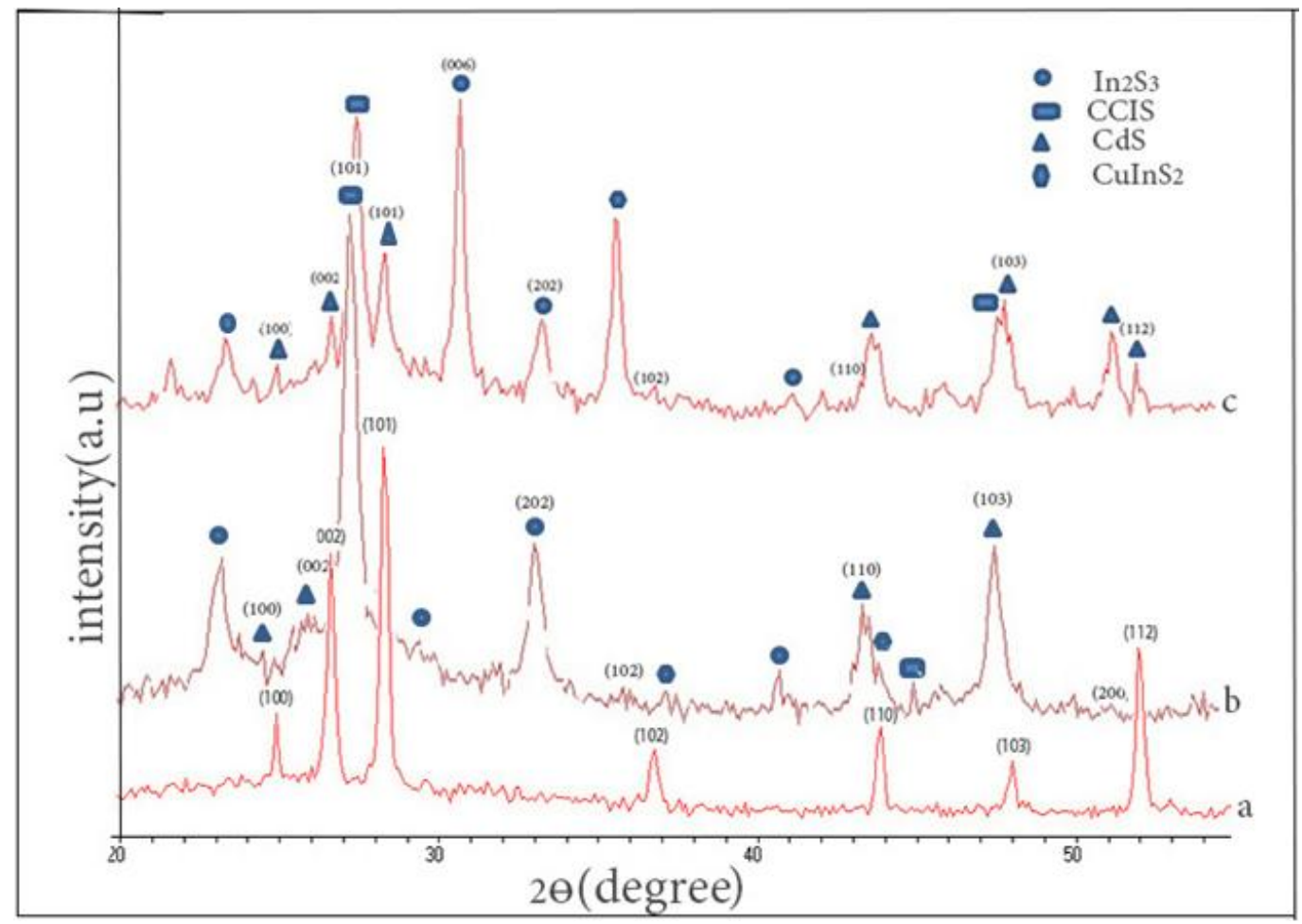

Fig. 1. X-ray diffraction patterns (a) CdS, (b) CCIS, and (c) ITO/CdS/CCIS

Ashour[17]. Fig. 1also shows that the heterojunction structure has $\mathrm{CuInS}_{2}, \mathrm{CdS}, \operatorname{In}_{2} \mathrm{~S}_{3}$, and CCIS peaks. The average grain size of CCIS is calculated from (FWHM) of the (101), and (002) by using the scherrer formula [15] 27, and 11, respectively. Typical CCIS film with $x=0.2$ and CdS film were morphologically characterized by using the AFM, as shown in Fig. 2,photographs of the films. The root mean square values of the surface roughness of CdS, and CCIS films are 5.4 , and $14.1 \mathrm{~nm} / 2 \mu \mathrm{m} \times 2 \mu \mathrm{m}$, respectively.

\section{B. Optical Properties}

The optical absorption and transmission spectra of CCIS, CdS, and ITO films were recorded in the 300 $\mathrm{nm}$ to $1100 \mathrm{~nm}$ range. The transmission $(\mathrm{T})$ spectra are important parameter for optical materials and applications. The $\mathrm{T}$ value which depends on wavelength $(\lambda)$ is shown in Fig.3. The peak values of $\mathrm{T}$ of the films, ITO, CdS, ITO/CdS are equal 75\%, 70\%, 58\% respectively. The absorption coefficient ( $\alpha$ ) was calculated using the following relation:

$$
\alpha=2.3 \frac{A}{t}
$$

where $A$ is absorption and $t$ is the film thickness.. Fig . 4 shows that the plot of $\alpha$ is the versus to the wavelength $\lambda$ of the films that have high values $\left(\alpha>10^{4} \mathrm{~cm}^{-1}\right)$ at visible range and then become nearly constant at NIR range. 
(a)

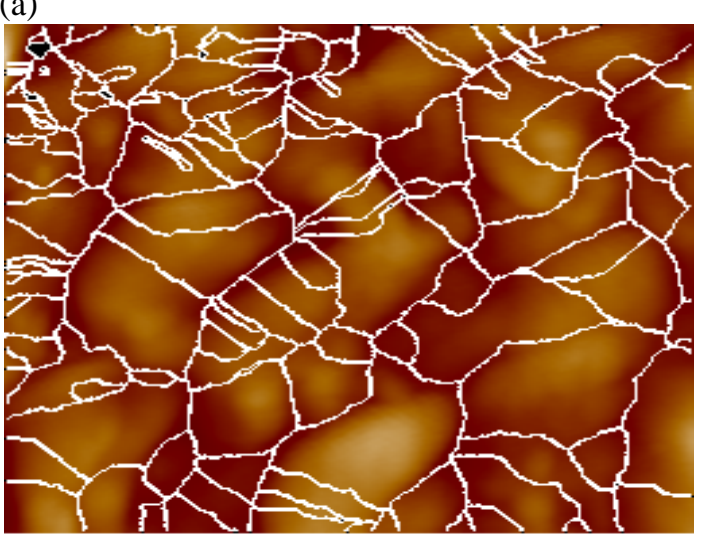

Pixels $=[256,256] \quad$ Size $=[2000.00 n m$,
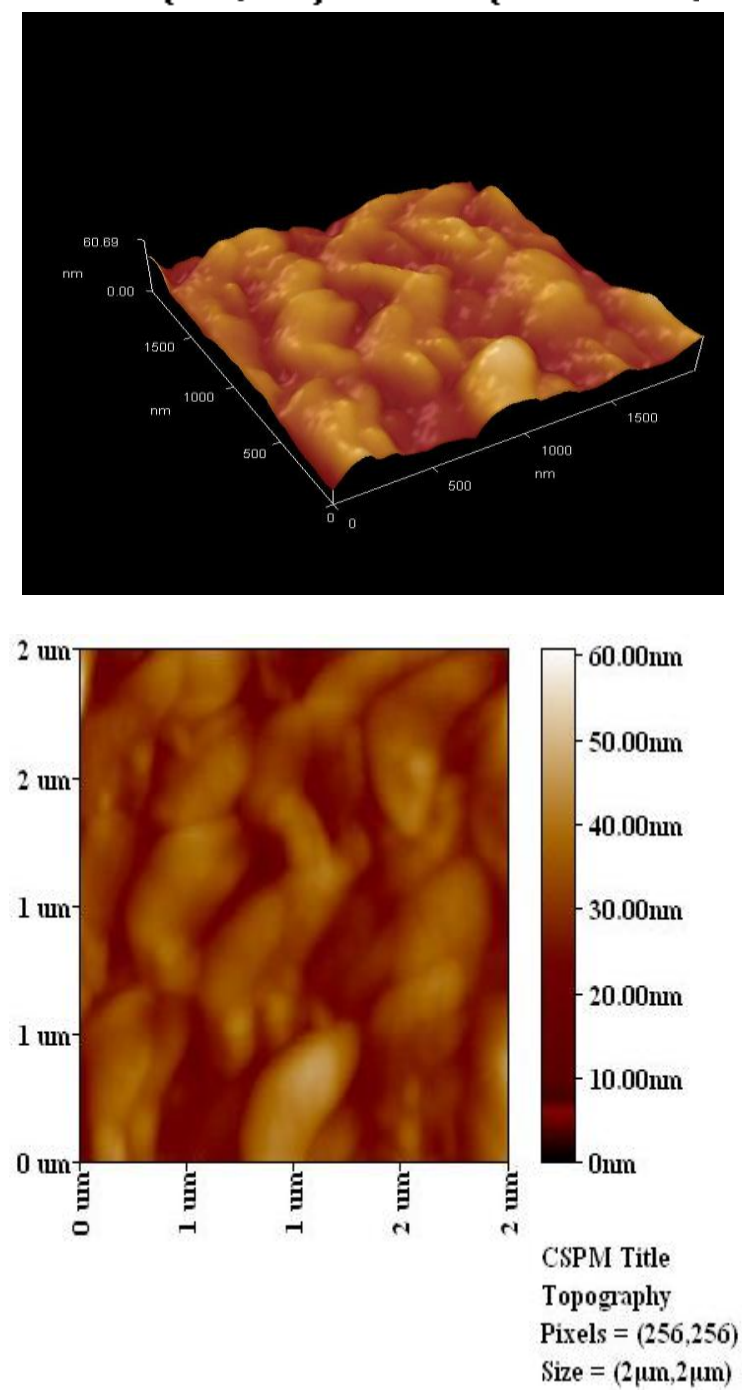

(b)

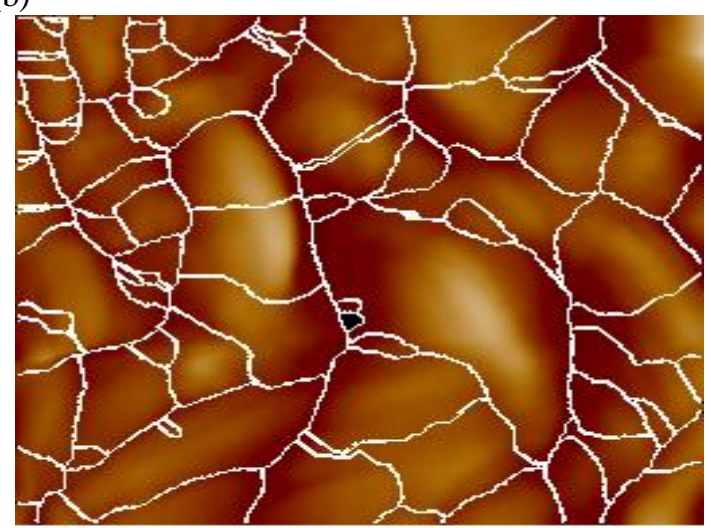

Pixels $=[256,256] \quad$ Size $=[2000.00 \mathrm{~nm}$
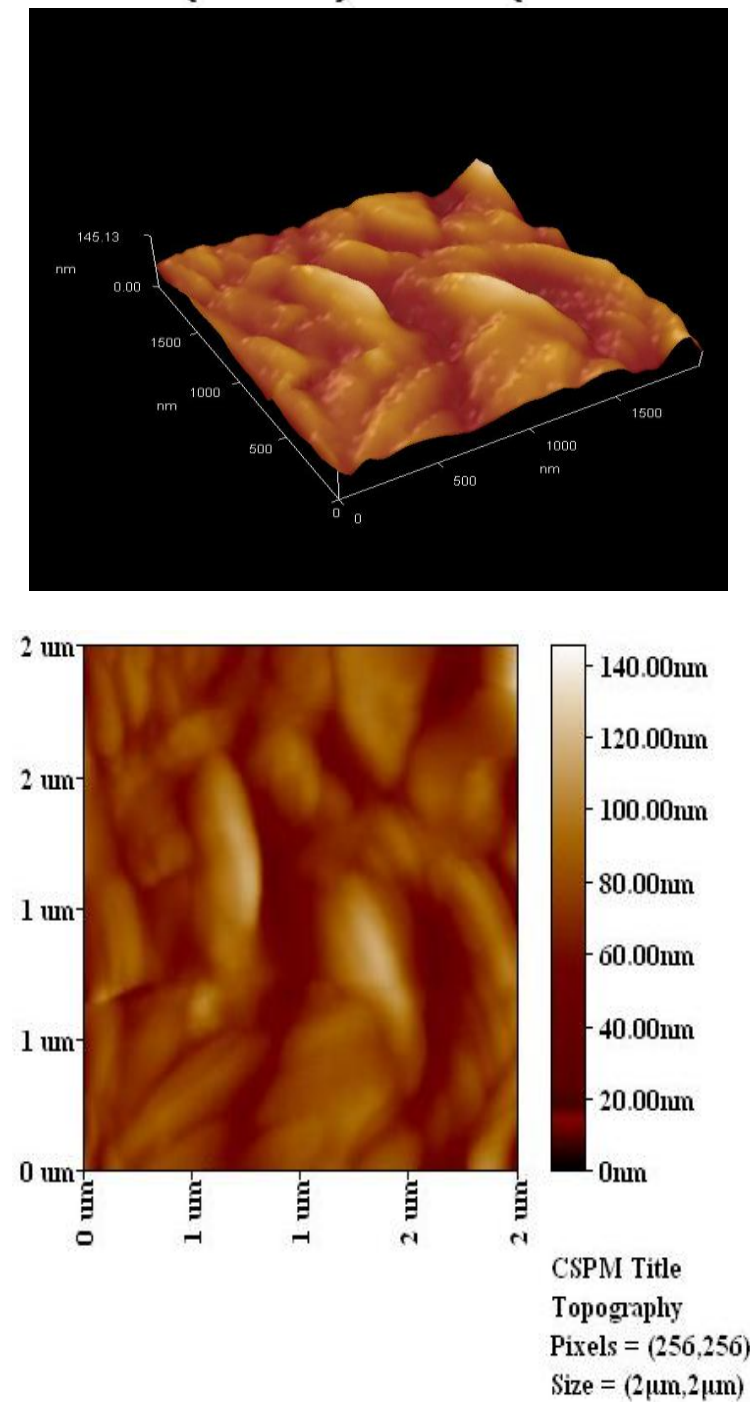

Fig. 2. AFM photographs of (a) CdS, and (b) CCIS.

The energy band gap of the films can be estimated from the tangent line in the plot of $(\alpha h v)^{2}$ with hu (fig.5). The band gaps of $\mathrm{CuInS}_{2}, \mathrm{ITO}$, and $\mathrm{CdS}$ are $1.4,3.6 \mathrm{eV}$, and $2.4 \mathrm{eV}$ respectively $[8,18,19]$. The energy gap of the films, CCIS, ITO, and CdSare 1.7, 3.52, and 2.42eVrespectively.

3. The transmission of (a) CdS, (b) ITO, and (c) ITO/CdS. 


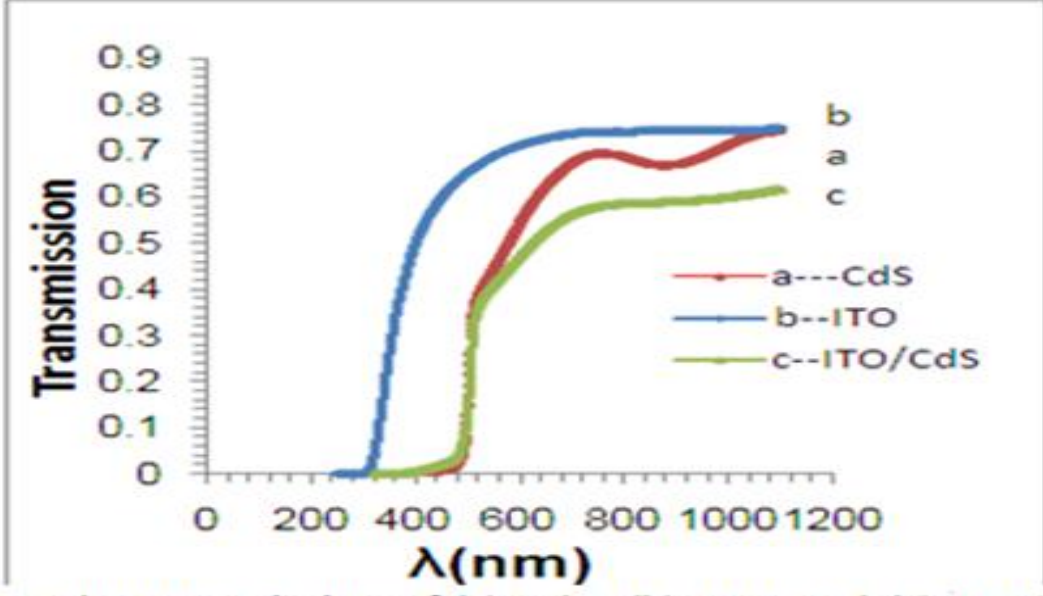

Fig. 3. The transmission of (a) CdS, (b) ITO, and (c) ITO/CdS.

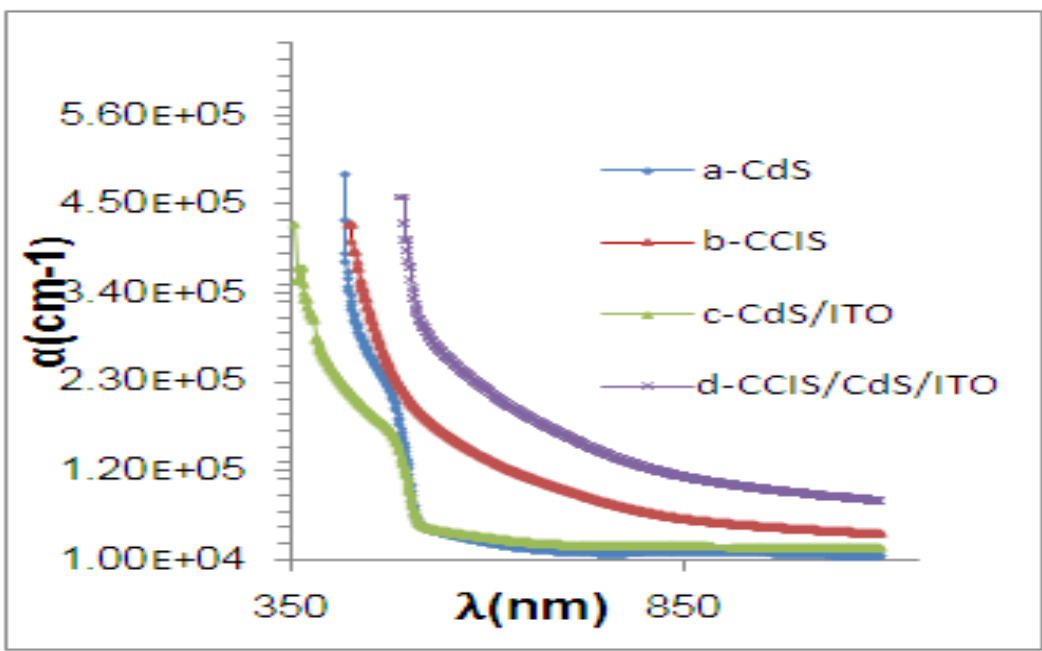

Fig. 4. The absorption coefficient ( $\alpha$ ) vs wavelength ( $\lambda$ ) for (a) CdS, (b) CCIS, (c) ITO/CdS, and (d) ITO/CdS/CCIS.

The refractive index (n) value which depends on hu, is shown in Fig. 6.The peak values of $\mathrm{n}$ of the films, CCIS, CdS, and ITO/CdS are equal 1.8, 2.6,and 2.5 respectively.

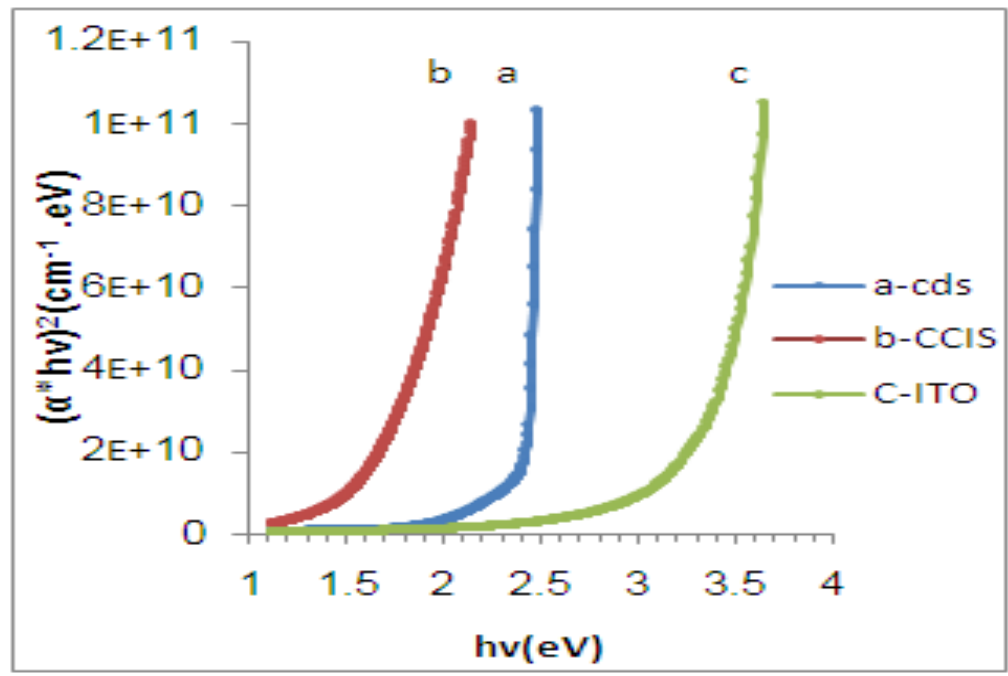

Fig. 5. The energy gap of the films, (a) CdS, (b) CCIS, and (c) ITO.

The extinction coefficient (k) value which depend on hu, is shown in Fig.6. The peak values of $\mathrm{k}$ of the films CdS, CCIS, and ITO/CdS were 1.2, 1.3, and 0.9, respectively shows in Fig. 7. 


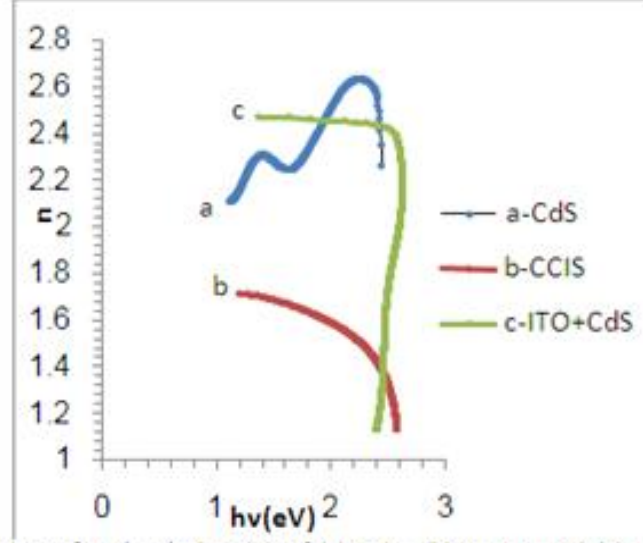

Fig 6. The refractive index (n) of (a) CdS, (b) CCIS, and (c) IT

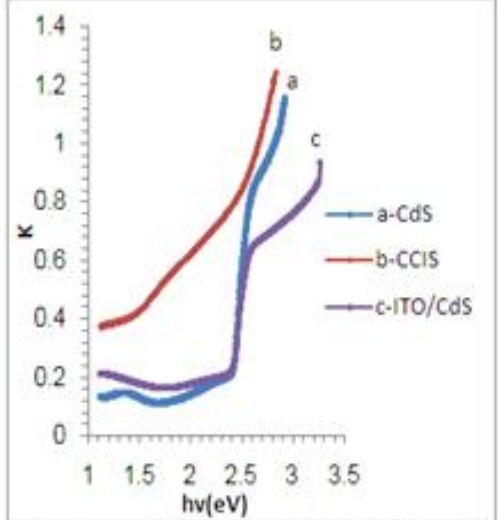

Fig. 7. The extinction coefficient of (a) CdS, (b) CCIS, and (c) ITO CdS.

\section{CONCLUSIONS}

The device ITO/CdS/CCIS was synthesized by using a simple chemical spray pyrolysis technique. The XRD shows that the film CdS have hexagonal and cubic structure, and the CCIS film has $\mathrm{CuInS}_{2}$ crystals in the chalcopyrite structure and CdS crystal and the hexagonal structure. The optical studies show that the films, ITO, CdS, and CCIS have direct optical energy gap 3.52, 4.42, and $1.6 \mathrm{eV}$. The surface morphology studies by AFM.

\section{REFERENCES}

[1]. A. Bollero, J.F. Trigo, J. Herrero, M.T. Gutierrez " Simplified modulated evaporation process for the production of $\mathrm{CuInS}_{2}$ films with reduced substrate temperatures" Thin Solid Films 517 (2009) 2167- 2170.

[2]. N. HamounAllouche, N. Jebbari, C. Guasch, N. KamounTurki، Influence of aluminum doping in CuInS 2 prepared by spray pyrolysis on different Substrates ، Journal of Alloys and compounds 501, 85-88 (2010).

[3]. T. Nakada, M. Mizutani, Y. Hagiwara and A. Kunioka Sol. Energy Mater. Sol. Cells 67 (2001) 255

[4]. G. Gordillo and C. Calderon Sol. Energy Mater. Sol. Cells 77 (2003) 163.

[5]. S. Spiering, D. Hariskos, M. Powalla, N. Naghavi and D. Loncot Thin Solid Films 431- 432 (2003) 359.

[6]. R. Naciri, H. Bihri, A. Mzerd, A. Rahioui, M. Abd-Lefdil and C. Messaoudi، The role of CdS buffer layer in the $\mathrm{CuInS}_{2}$ Thin film solar cell ، Revue des Energies Renouvelables CER، 07 Oujda (2007) 165-168.

[7]. Yong-Duck Chung, Dae-Hyung Cho, NaeMan Park, Kyu-Seok Lee, Jeha Kim “ Effect of annealing on $\mathrm{CdS} / \mathrm{Cu}(\mathrm{In}, \mathrm{Ga}) \mathrm{Se}_{2}$ thin film solar cells “ C Current Applied physics 11, 565-567(2011).

[8]. Lu Ren, Fan Yang, Yu-Rong Deng, Nan-Nan Yan, Sheng Huang, Dan Lei, Qiang Sun, Ying Yu " Synthesis of $(\mathrm{CuIn})_{\mathrm{x}} \mathrm{Cd}_{2(1-\mathrm{x})} \mathrm{S}_{2}$ photocatalysts for $\mathrm{H}_{2}$ evolution under visible light by using a low-temperature hydrothermal method" international journal of hydrogen energy 35, 3297-3305(2010).

[9]. K.L. Choy and B. Su, Thin Solid Films, Vol. 388, p. 9, 2001.

[10]. O. Cojocara-Miredin, P. choi, R. Wuerz, and D. Raabe " Atomic-scale characterization of the CdS/CuInSe2 interface in thin-film solar cells" Appl. Lett. 98, 103504 (2011); doi: 10. 1063/1.3560308.

[11]. M.D. MAHANUBHAV, L.A. PATIL, P.S. SONAWANE, P.H. BARI, V.R. PATIL "Structure and Optical Properties of Chemically Deposited Nanocrystalline Thin Film of Non-Stoichiometric $\mathrm{CuInS}_{2}$ " Sensors \& Transducers Journal, Vol.73, Issue 11, November 2006, pp.826-833.

[12]. L.P. Marushko, L.V. Piskach, Y.E. Romanyuk, O.V. Parasyuk, I.D. Olekseyuk, "Quasi-ternary system $\mathrm{CuGaS}_{2}-$ $\mathrm{CuInS}_{2}$-2CdS" Journal of Alloys and Compounds 492,184-189(2010).

[13]. Hamid S. AL-Jumaili and Ahmed F. Awad "Structural, Optical, and Electrical Properties of Nanoparticle $2(\mathrm{CdS})_{\mathrm{x}}\left(\mathrm{CuInS}_{2}\right)_{1-\mathrm{x}}$ Thin Films Prepared by Chemical Spray Pyrolysis" Asian Transactions on Science \& Technology (ATST ISSN: 2221-4283) Volume 02 Issue 02, May (2012).

[14]. A.A. Yadav, M.A. Barote, E.U. Masumdar "Study on nanocrystalline Cadmium Sulphide (CdS) thin films deposited spray pyrolysis" Solid State sciences 12(2010) 1173-1177.

[15]. Rajesh A. Joshi, Vidya S. Taur, Ramphal Sharma "Polymer impinged CdS/CuInSe 2 solar cell" Solar Energy 86 (2012) 301-306.

[16]. K. Ravichandran, P. Philominathan "Investigations on microstructural and optical properties of CdS films fabricated by a low-cost, simplified spray technique using perfume atomizer for solar cell applications" Solar Energy 82 (2008) 1062-1066.

[17]. $\quad$ A. ASHOUR "Physical Properties of Spray PyrolysedCdS Thin Film" Turk J Phys, 27 (2003), 551-558.

[18]. A. El Hichou, A. Kachouane, J.L. Bubendorff, M. Addou, J. Ebothe, M.Troyon, A. Bougrine " Effect of substrate temperature on electrical, structural, optical and cathodoluminescent properties of In2O3-Sn thin films prepared by spray pyrolysis" Thin Solid Films 458 (2004) 263-268.

[19]. A. Kariper, E. Guneri, F. Gode, C. Gumus, T. Ozpozan " The structural, electrical and optical properties of CdS thin films as a function of PH" Materials Chemistry and Physics (2011). 